\title{
Comparison of the Effectiveness of Cognitive-Behavioral Group Therapy and Hope-Based Group Therapy on Pain Perception in Patients with Multiple Sclerosis (MS)
}

\begin{abstract}
Background and Objective: In patients with multiple sclerosis, pain is a common phenomenon and plays an important role in mental health and quality of life of these individuals. Therefore, the purpose of this study was to compare the efficacy of cognitive behavioral group therapy and hope-based group therapy on perception of pain in patients with MS.

Materials and Materials and Methods:This is a quasi-experimental study with pretest and post-test design and control group. 45 patients were randomly selected from MS patients with pain who referred to neurological and neurology specialists in Karaj, Iran , in the first six months of 2017. The participants were assigned to three groups with 15 subjects (two intervention groups and one control group). Each intervention group was treated for 8 sessions and the control group did not receive cognitive behavioral interventions and hope-based therapy. Pain perception was measured in pretest and posttest with Pain Questionnaire (MPQ).

Results: Independent results showed that both cognitive-behavioral therapy and hope-based therapy had a significant effect on pain relief in MS patients ( $P=0.05)$. Also, the effect of cognitive-behavioral therapy on emotional pain was significantly different from that of hope-based therapy $(P<0.05)$.

Conclusion: The results indicated the importance of both methods, especially cognitive behavioral therapy, in reducing pain perception in patients with MS. Therefore, counselors and therapists can use both methods to reduce pain in these patients.

Keywords: Hope-based therapy, Cognitive-behavioral therapy, MS

Paper Type: Research Article.
\end{abstract}

Citation (Vancouver): Rezaeinasab F, Borjali A, Taghdisi M. Comparison of the Effectiveness of Cognitive-Behavioral Group Therapy and Hope-Based Group Therapy on Pain Perception in Patients with Multiple Sclerosis (MS). Iran J Health Educ Health Promot. Autumn 2019;7(3): 360-372. [Persian]

Citation (APA): Rezaeinasab F., Borjali A., Taghdisi M. (Autumn 2019). Comparison of the Effectiveness of Cognitive-Behavioral Group Therapy and Hope-Based Group Therapy on Pain Perception in Patients with Multiple Sclerosis (MS). Iranian Journal of Health Education \& Health Promotion., 7(3), 360-372. [Persian]

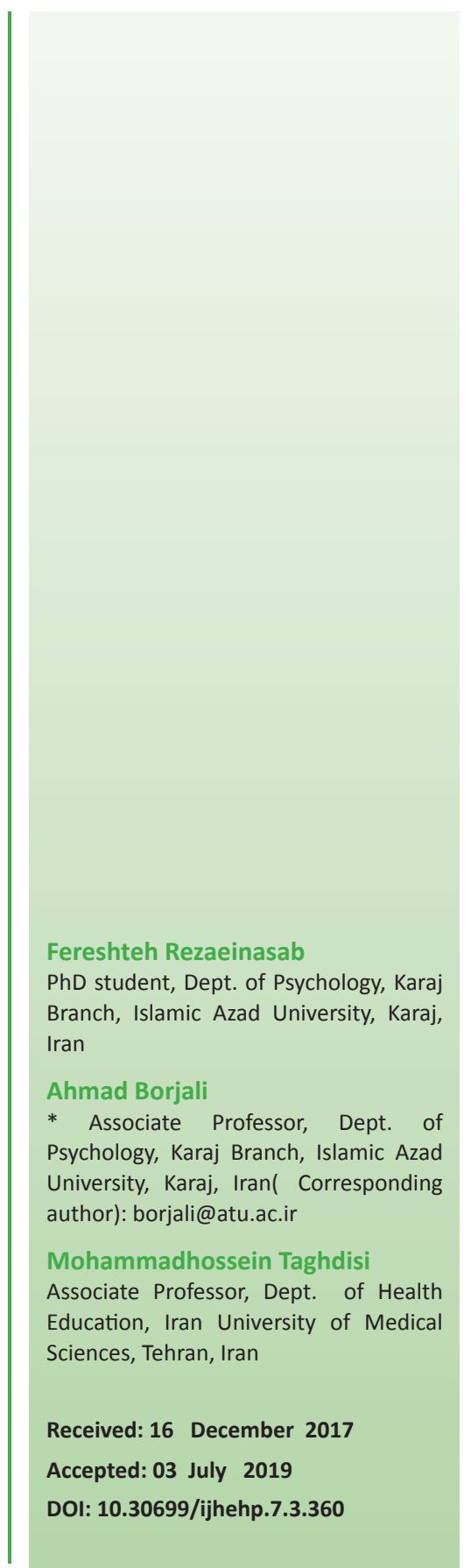




\section{مقايسه اثربخشى كروه درمانى شناختى - رفتارى و كروه درمانى مبتنى بر اميده

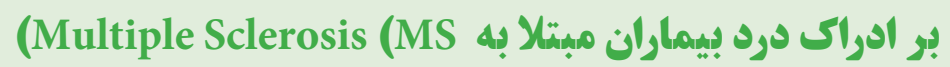

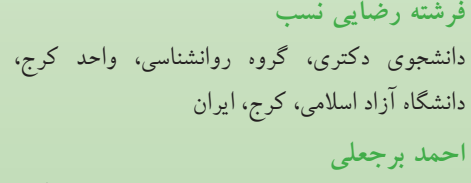

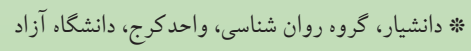
borjali@atu.ac.ir

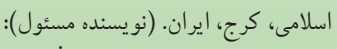
محمد حسين تقد يسى

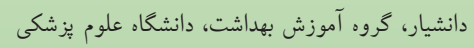
ايران، تهران، ايران

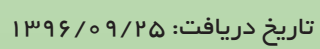

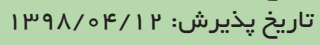

\section{OU}

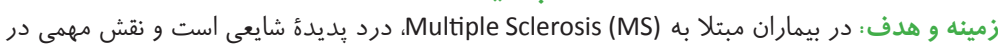

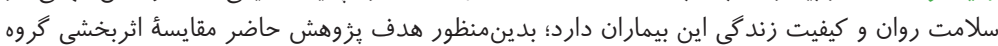

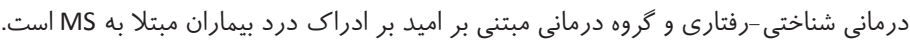

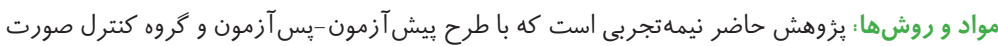

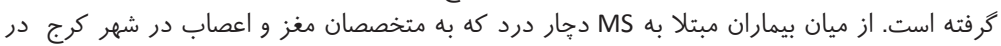

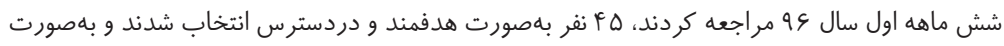

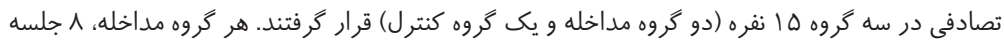

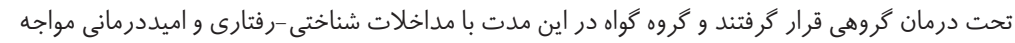

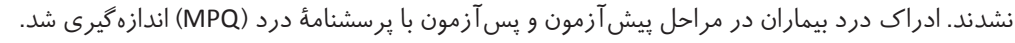

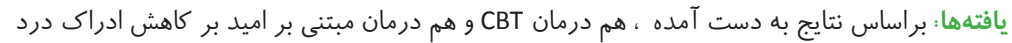

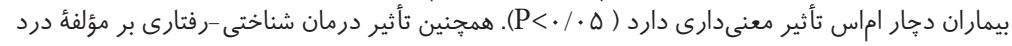

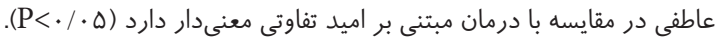

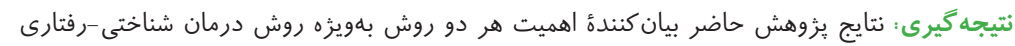

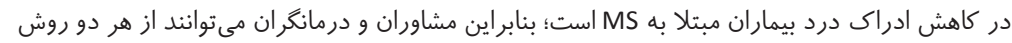

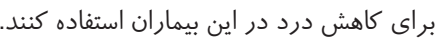

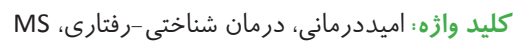
نوع مقاله : مطالعه يزوهشى.

ا استناد (ونكوور) : رضايى نسب ف، برجعلى ا، تقديسى م. مقايسة اثربخشى گروه درمانى شناختى - رفتارى

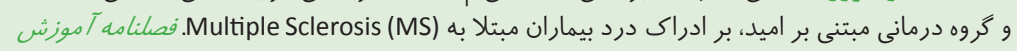

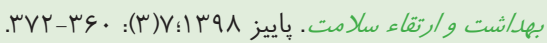

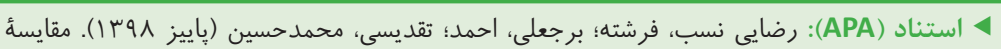

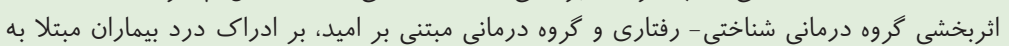

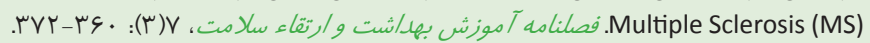


اين بيمارى شامل اضطراب، استرس، افسردگى، اختلالات شناختى،

تحريك يذيرى و عصبانيت است ( •(1).

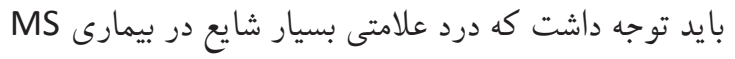

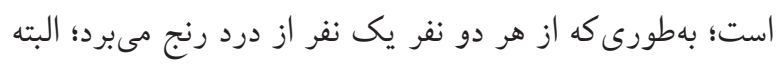

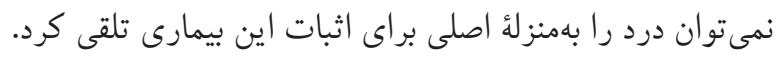

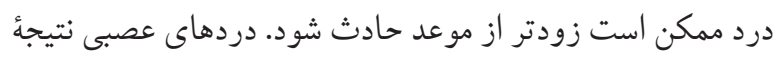
مستقيم بيمارى هستند كه به سيستم اعصاب مر كزى مر بوط مى شود.

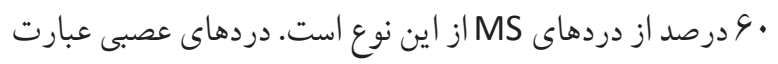

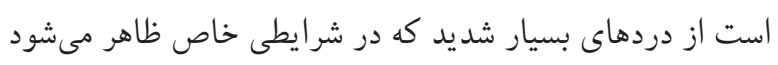

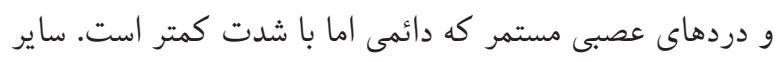
دردها عبارتاند از دردى كه به انقباض شديد عضلات شبيه است، دردهاى شديد سطحى يا سوزشى، دردهاى ثانويه مثل كمردرد و...

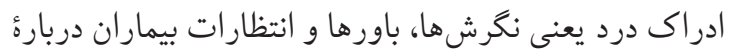

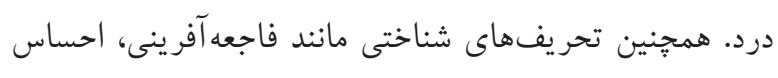

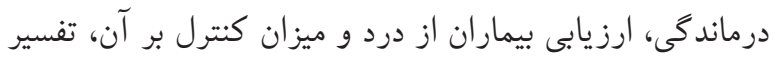

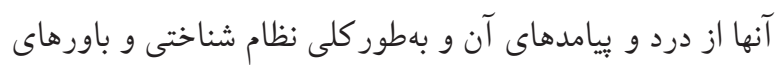

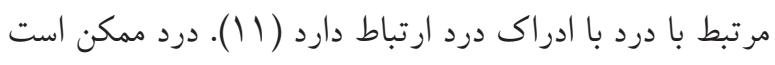
منشأ جسمى يا ذهنى، عضوى يا كار كردى و طبى يا روانى داشته دئه

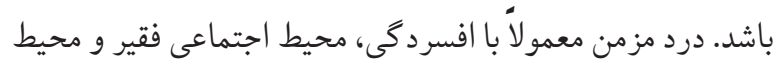

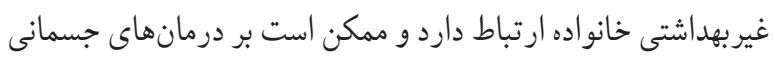

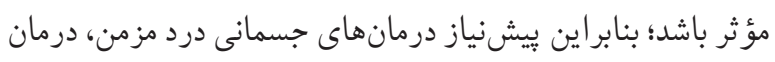
عاطفى و ديكر مشكلات روانشناختى است.

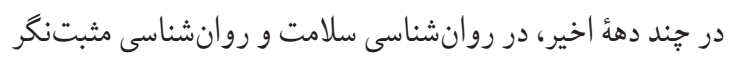

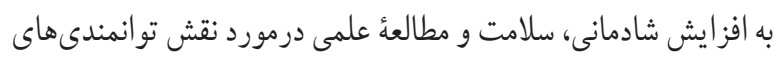
شخصى و سامانهاى اجتماعى مثبت در ارتقاى سلامت بهينه تأكيد

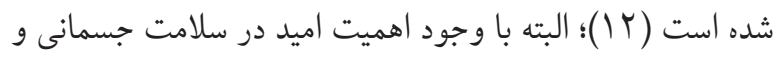
روانى، در كذشته توجه جندانى به آن نشده بود، اما در جنبش جديد

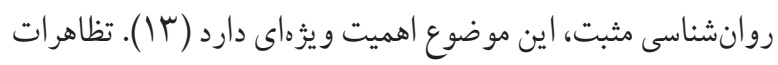

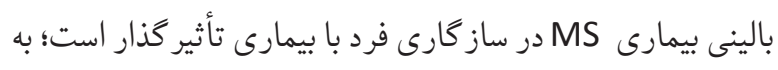

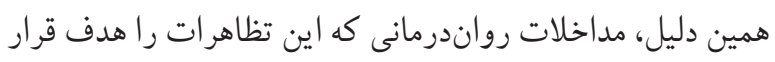

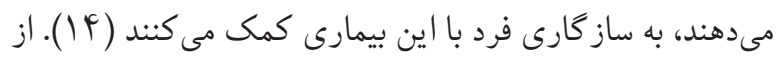
Multiple Sclerosis يا نوعى بيمارى ييشرونده و تحليل برندة غلاف ميلين سلولهاى عصبى در سيستم عصبى مركزى است (1)

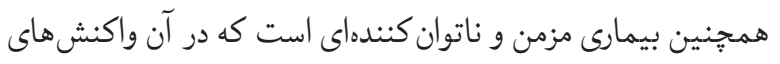
ايمنى به ميلين غلاف آكسونها در سيستم اعصاب مركزى مغز و و نخاع آسيب مىرساند (Y). اين بيمارى التهابى است كه در آن آن غلافهاى ميلين سلولهاى عصبى در مغز و نخاع آسيب مى بينند

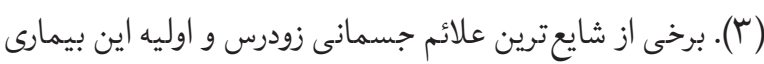

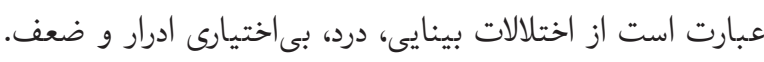

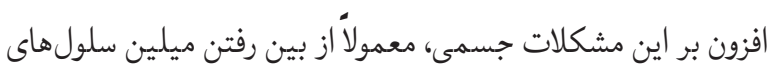

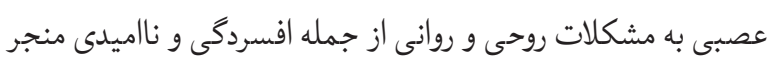

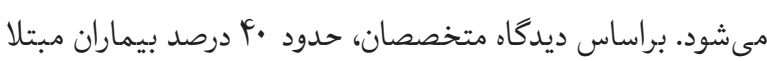

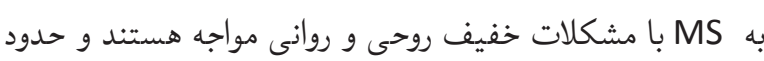

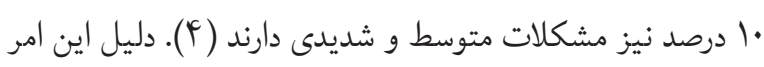
نامعلوم است، اما مطالعات بر عفونت ويروسى و اختلالات سيستم

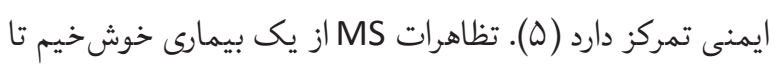

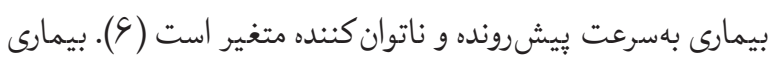
MS

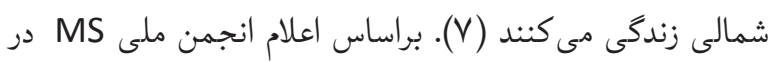

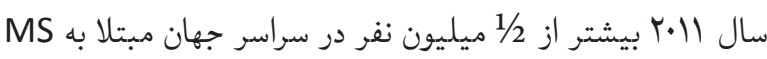

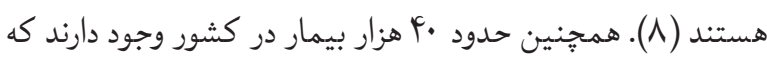

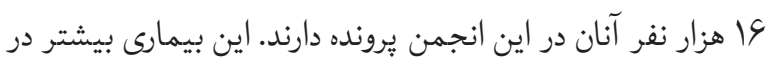

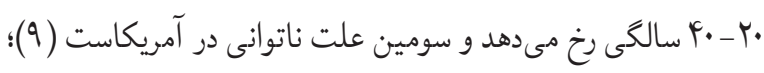
شيوع اين بيمارى در اين سنين به اين دليل است كه فرد بيشترين

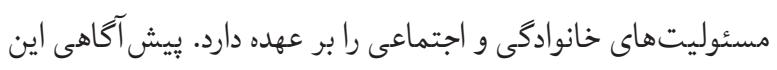

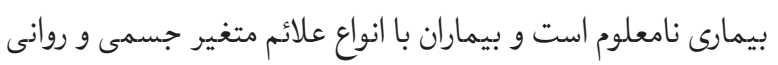

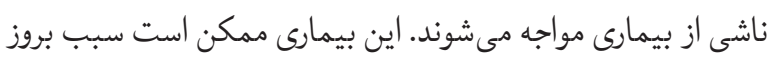

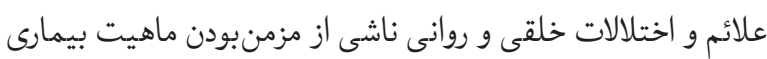

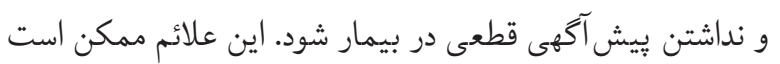
در نتيجهُ تأثير مستقيم التهاب و دميلينهشدن اعصاب يا تأثيرات دئي

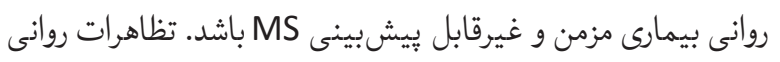


مستقيم با افكار و احساسات كه در همهٔ اختلالهاى روانى اهميتى آشكار دارند مرتبط است و شكافى را كه بسيارى از درمانكران

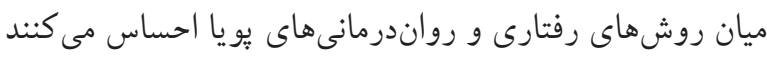

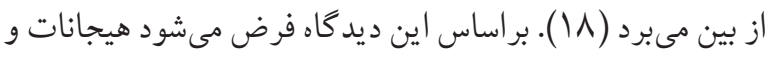

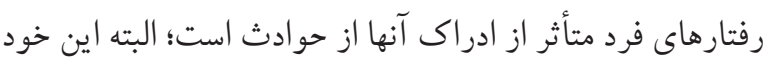
موقعيت نيست كه احساس افر اد را مشخص مى كند. هدف اين مدل درمانى تغيير افكار و معانى اختصاصى است. تكاليف رفتارى نيز به

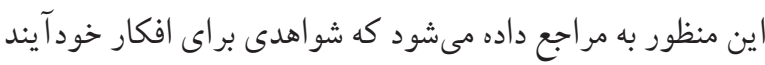

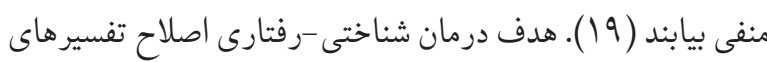

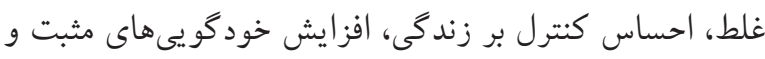

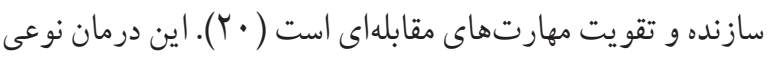
رفتاردرمانى در بطن موقعيتهاى رواندرمانى سنتى و منعكس كنندة علاقه فز ايندة درمانكر ان به اصلاح شناخت (عامل مؤثر بر هيجانها

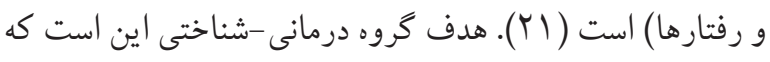

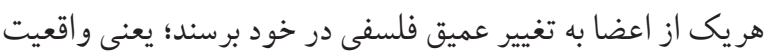

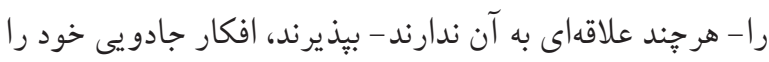

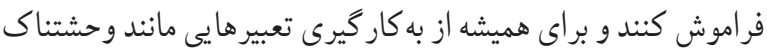

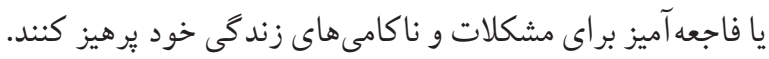

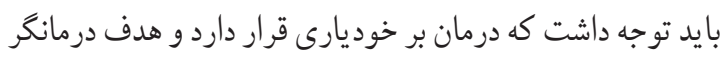

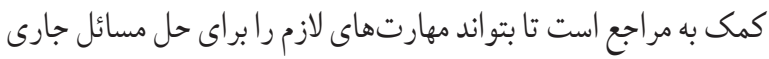

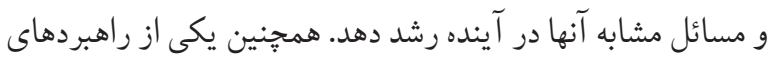

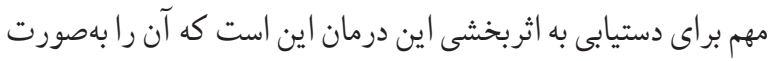

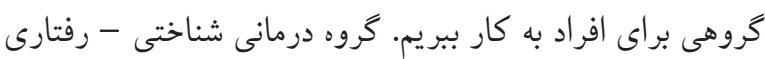

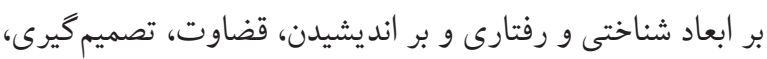

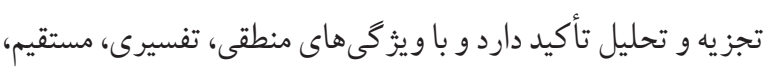

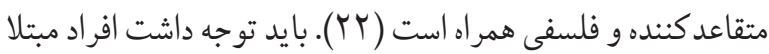

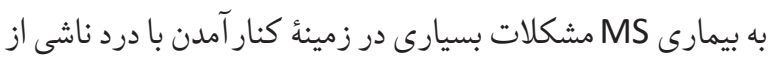

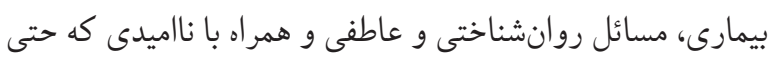

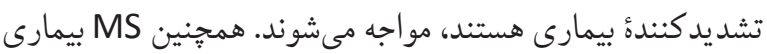

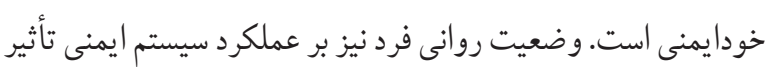

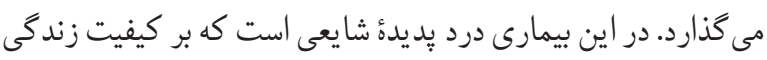

آنجا كه اين بيمارى يكى از عوامل تهديد كنندهٔ اميد است، برداختن

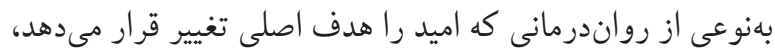

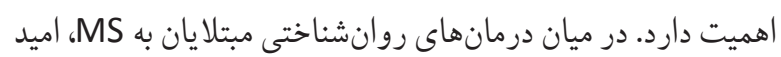
درمانى Schneide تنها درمانى است كه اميد را هدف اصلى قرار داده است. همجينين با تر كيب اصول مداخلات مبتنى بر شرح حال و تمركز بر حل مسئلة مشكلات شناختى -رفتارى، نظام درمانى دانى

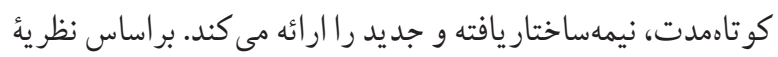

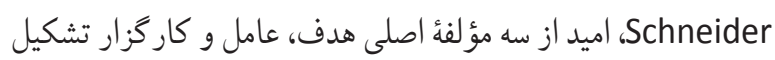

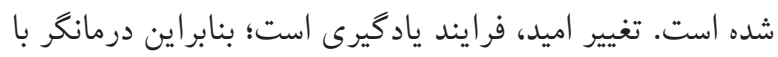

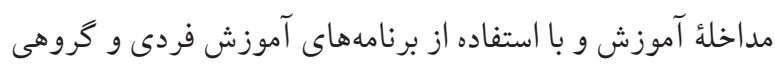

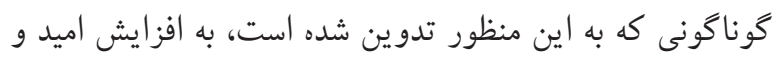

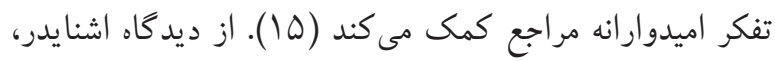

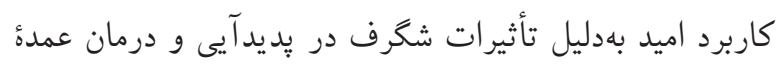

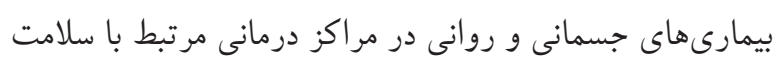

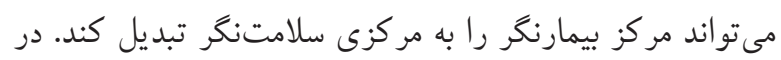

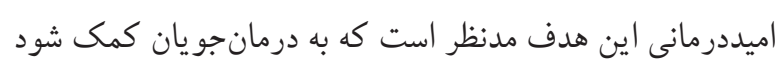

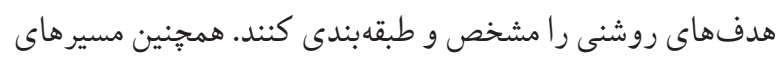

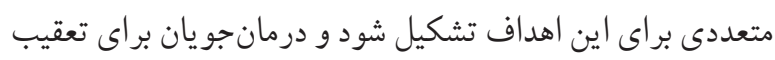

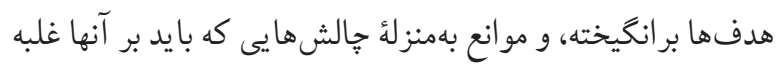

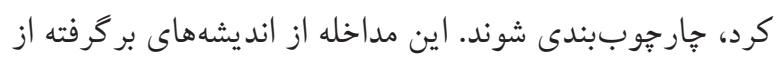

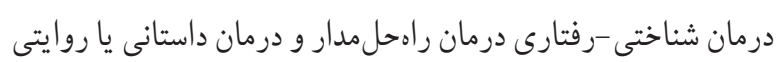

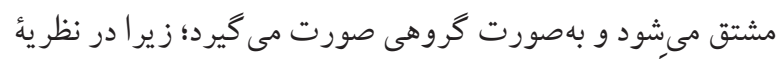
اشنايدر فرض بر اين است كه تفكر اميدوارانه در فرايند تبادلى ونى

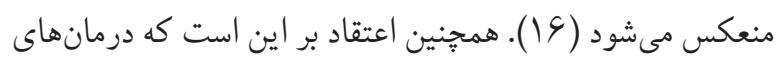

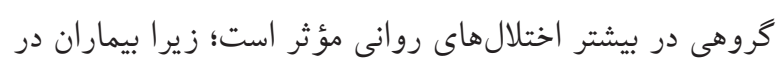

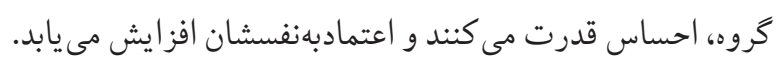

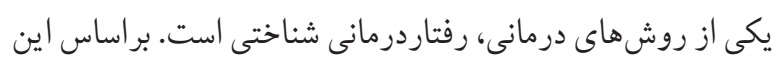

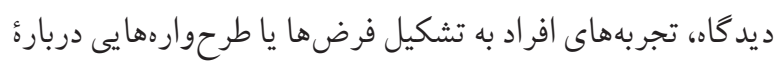

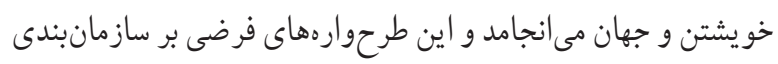

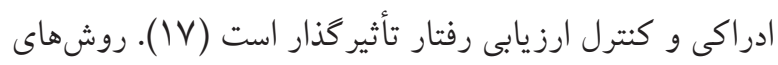

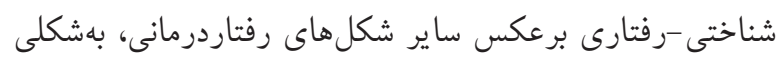


شد و افراد نمونه در يكى از كلينيكهاى روانشناختى شهر كرج در

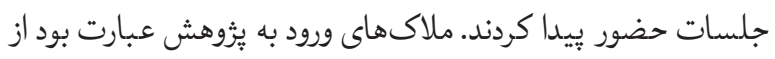

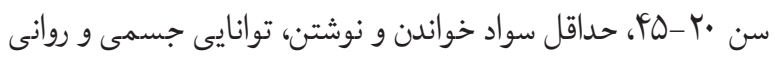

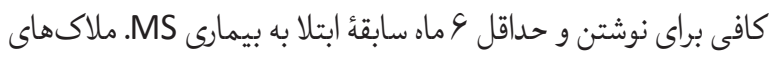

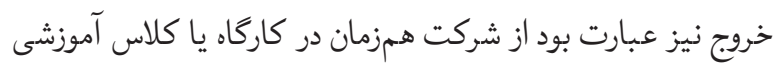

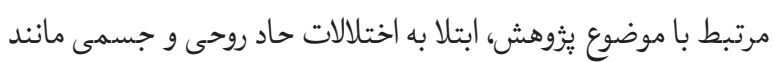
بيمارىهاى ناتوان كنندة قلبى، تنفس و افسردكى شديد، اسكيزوفرنيا، داشتن اختلال در تكلم يا شنوايى و سوءمصرف مواد. يرسشامل ادراى درد مك گيل (MPQ) سنجش ابعاد درد به كمك برسشنامهٔ درد مك گيل صورت گرفت. اين يرسشنامه شامل بيست مجموعه كلمه است كه دربركيرندة جهار

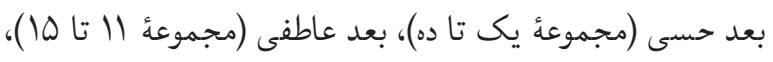

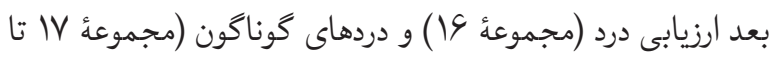

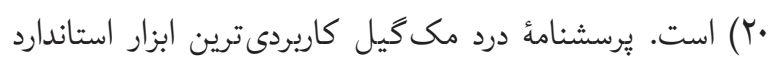

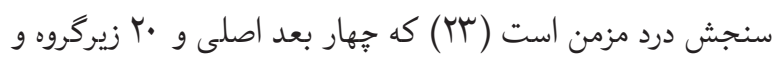

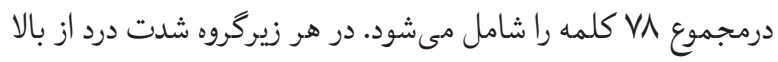

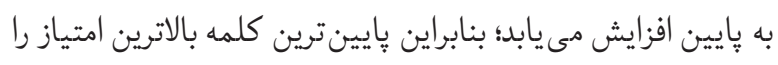

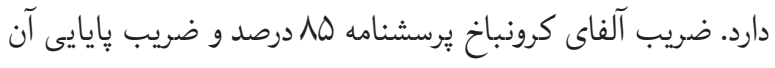

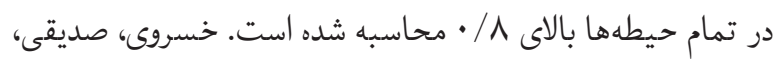

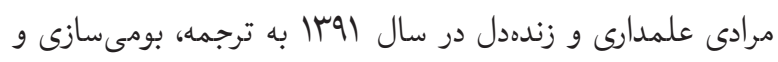

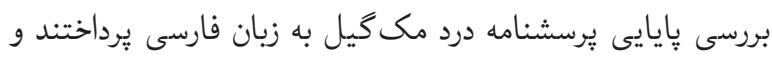

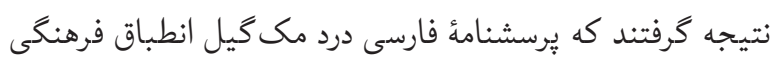

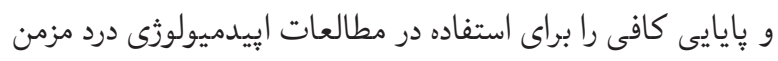

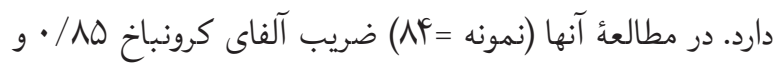
ضريب پايايیى در تمام حيطهها (حسى، عاطفى، ارزيابى، شناختى و

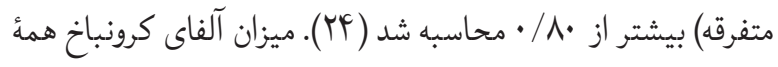

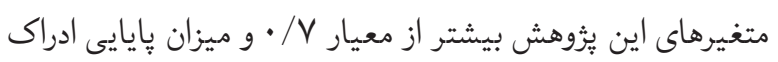

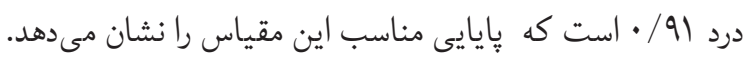
روند اجراى يزوهش به اين صورت بود كه بس از دريافت مجوز

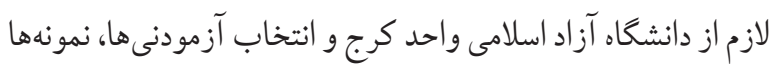

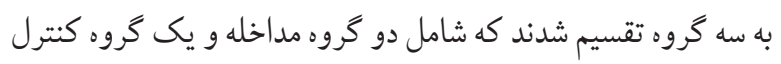

و سلامت روان آنها تأثير منفى مى گذارد؛ بنابراين بهمنظور ارتقاى

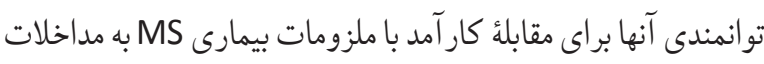
روانشناختى نيازمنديم كه در اين صورت ممكن است روشهاى به درمان بهان

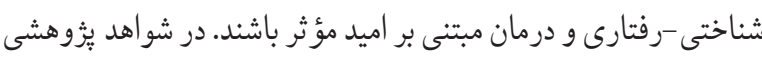
تاحدودى به اثربخشى مداخلات شناختى رفتارى و اميددرمانى بر علائم روانشناختى، كيفيت زندگى و... بيماران مبتلا به MS توجه شده است، اما نمونهُ يُزوهشهايى كه بهطور مشخص به مقايسة اثربخشى درمان

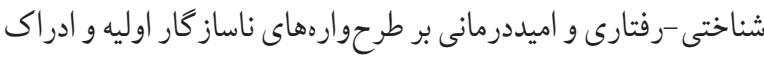

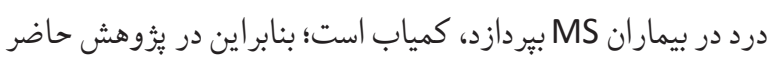

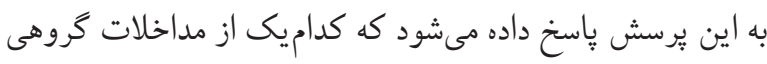

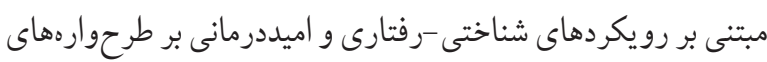

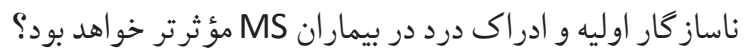

$$
\text { مو اد و روش ها }
$$
يُوهش حاضر از نوع كاربردى و مطالعهاى نيمه تجربى (نيمه آزمايشى) است كه دو گروه مداخله و يك گروه كنترل را شامل مى شود. جامعل

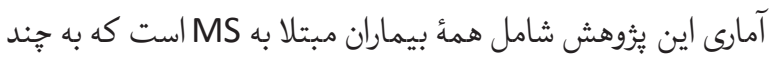
نفر از متخصصان مغز و اعصاب در شهر كرج مراجعه كرده بودند.

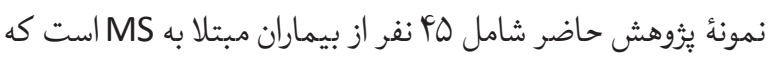
به روش دردسترس و هدفمند براساس ملاكهاى ورود به يُزوهش و

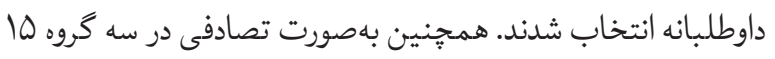

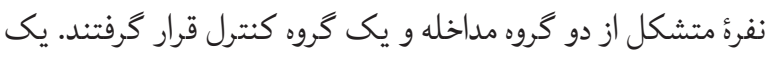

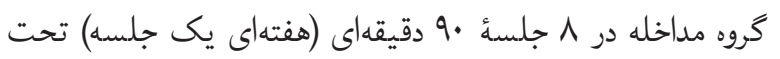
آموزش گروهى رفتار درمانى-شناختى قرار گرفت و گرووه مداخله

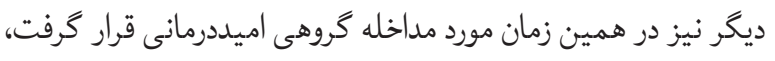

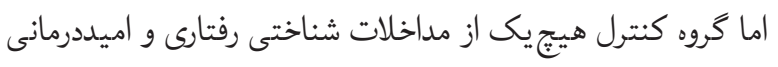
را دريافت نكرد. همهُ نمونها در دو مقطع بيش آزمون و يس بـ آزمون

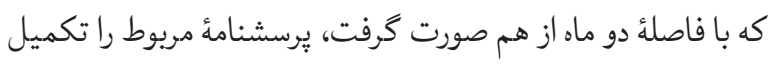

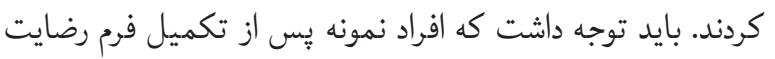

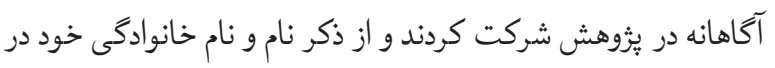
يرسشنامها معاف بودند. بِرسشنامهها نيز با حروف اختصارى كدگذارى تردي 
در جلسات جهارم و ينجم صورت گرفت. جلسؤ ششم شامل مرور تكاليف جلسة قبل، تهية فهرست اصلى باورها، نقشههاى شناختى و درجهبندى واحدهاى نار احتى ذهنى و ارائُة تكليف بود. در جلسئ

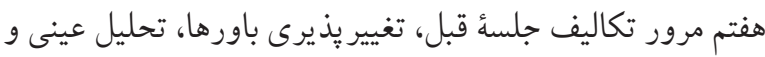
تحليل هم سانى باورها صورت گرفت. در جلسؤ هشتم نيز به مرور

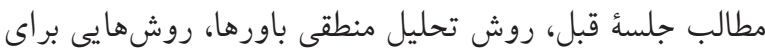

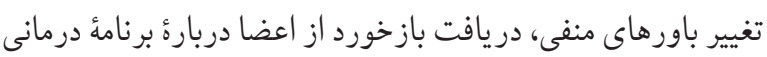

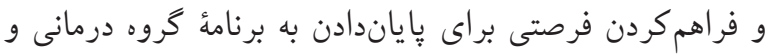

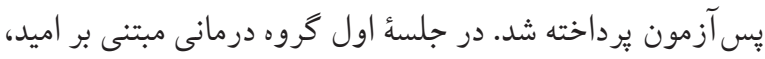

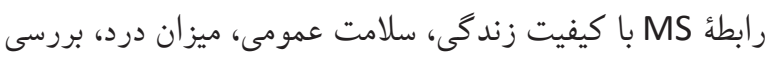

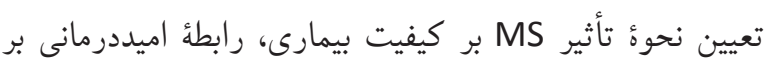
MS شد. در جلسهُ دوم، به شناخت مشكل كلى بيمار، به كار گيرى فنون اميددرمانى، روشهاى درمانى تسكينى و نفوذى (كوشدادن توجه آميز و همدلانه)، سنجش مشكلات بيماران در حيطة اميد و بيان رابطة آن رونان با ميزان كنترل در دو طرحواره صورت كرفت. جلسهُ سوم شامل ارائٔ اهداف و تو افق بر سر دستور كار، حفظ اتحاد درمانى و استفاده

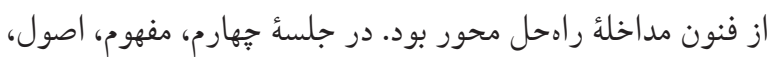

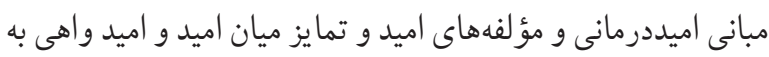

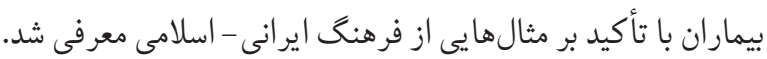

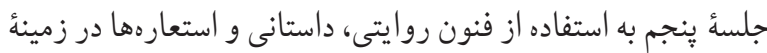
اميد با تأكيد بر نقش اميددهى در اديان بهويزه دين اسلام بهمنظور

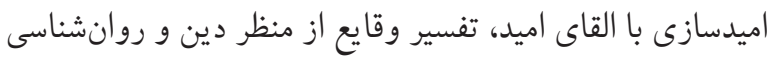
مثبت اختصاص يافت. در جلسؤ ششم، جهت دادن بيماران به زمان

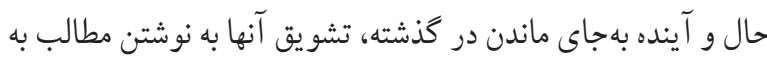

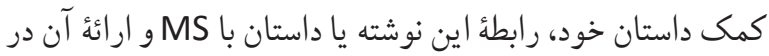
جلسهُ درمان صورت كرفت. همجنين جلسهُ هفتم شامل كوشدادن به داستان بيماران با توجه به تكليف ارائهشده در جلسةٔ قبل، ادامهٔ

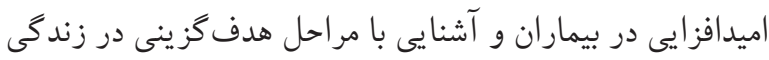

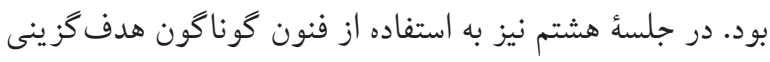
و خلق اهداف روشن و عملى، رفع موانع ذهنى اميد با استفاده از
بو دند. يُزوهشكُ ان محتواى مداخلهُ درمان شناختى -رفتارى را براساس

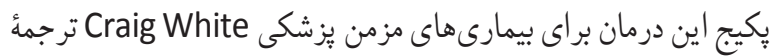

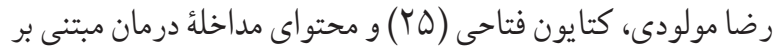
اميد براساس ويكيج اميددرمانى Schneider بركرفته از كتاب مبانى

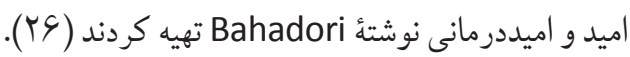
جلسةُ اول به معارفه، آشنايى با قوانين و اهداف كروه، بيان هدف جلسه، آشنايى با فرايند CBT ارائهُ تكليف، آشنايى بيماران

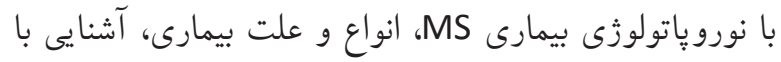

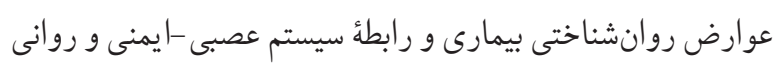
اختصاص يافت. در جلسهُ دوم به مرور تكاليف، آكاهى اعضا از

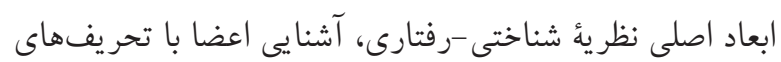

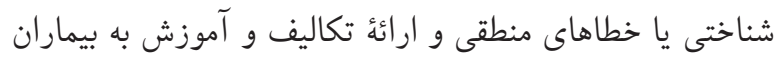

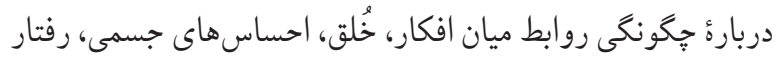

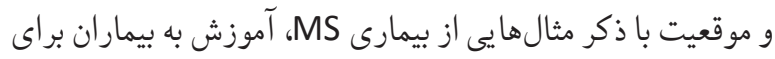
تشخيص و درجهبندى حالات خُلقى خود و آموزش روانى دربارة علائم روانشناختى شايع در اين بيماران برحسب منابع علمى و وركي

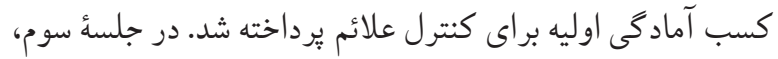

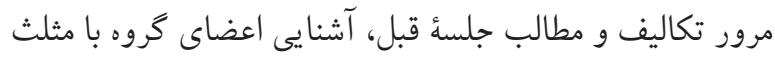
شناختى منفى، خطاهاى منطقى و ار ائٔ تكاليف، توضيح منطق مهار

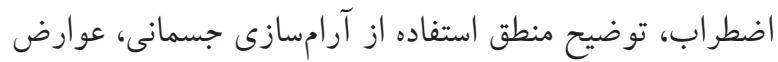

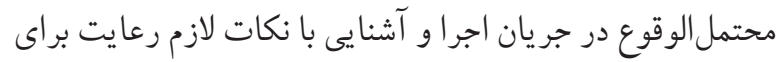
تسهيل اجراى تكنيك، توضيح منطق استفاده از تكنيك كنترل تنفسى و عوارض محتمل الوقوع در جريان اجراى تكنيك صورت

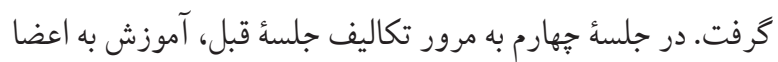

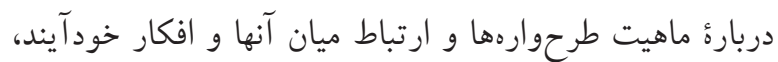

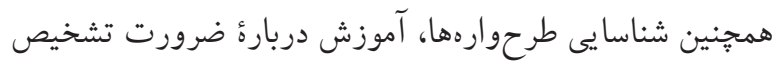

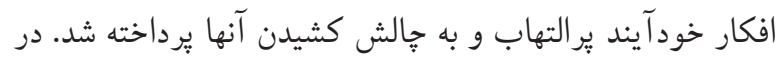

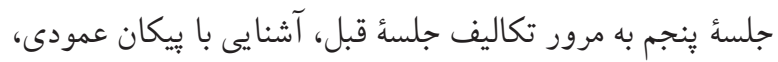

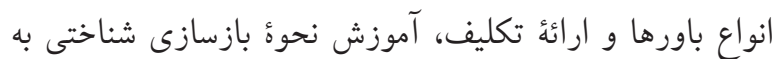

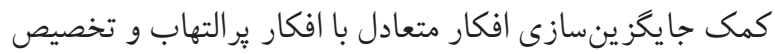
بخشى از وقت جلسه به يرسشهاى بيماران دربارءٔ مطالب مطرح 
يُزوهش در مراحل يِش آزمون و يس آزمون معنادار نبودند.كه نتايج آنها در جداول شماره با، أ، ه آمده است.

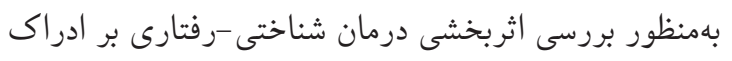

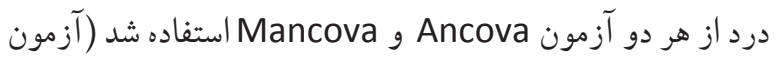
Ancova Mancova

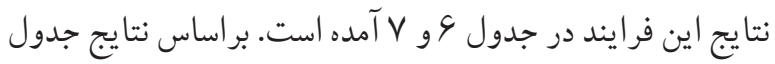

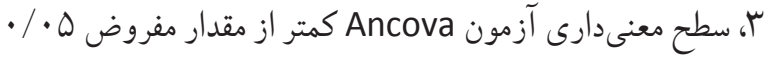

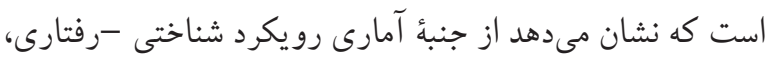

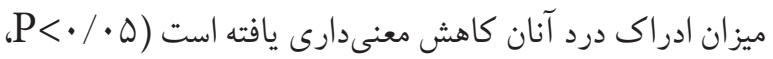
(F=rN/GY جشمخير رويكرد شناختى -رفتارى را بر ادراك درد نشان مىدهد. در جدول \نتايج آزمون Mancova با هدف تعيين اثر رويكرد

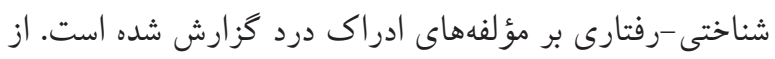
آنجا كه ادراك درد جهار مؤلفه دارد، بايد از آزمون Mancova

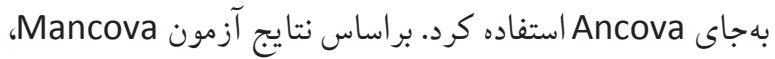
رويكرد CBT بر همة مؤلفههاى ادراك درد تأثير معنىدارى دارد

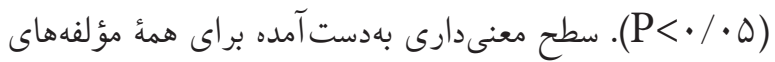

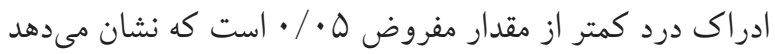

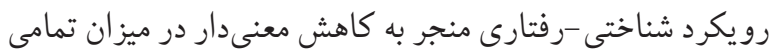

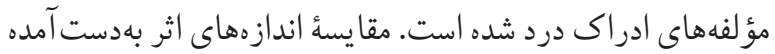
نشان مىدهد بيشتر ين اندازه اثر به مؤلفههاى ارزيابى درد ( 199 • • )

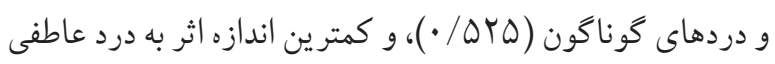

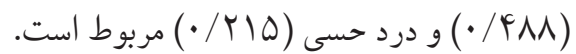
بهمنظور سنجش اثربخشى گروه درمانى مبتنى بر اميد بر ادراك دراك

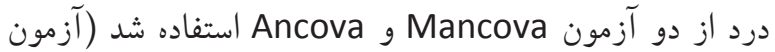
Ancova

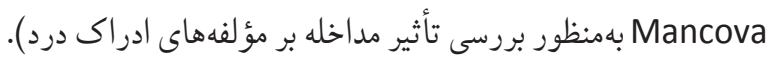

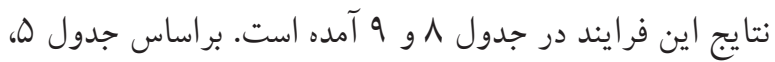

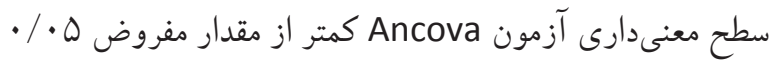

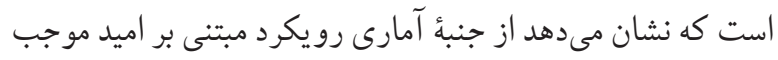

فنون اميددرمانى و درنهايت پِ آزمون بِرداخته شد. كلاسها در يكى از كلينيكهاى كرج بركزار شد. در بخش يافتهاى استنباطى،جهت سنجش بيش فرضها و بررسى نرمال بودن

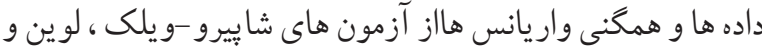
ام باكس Box's M و بهمنظور توصيف و تحليل دادهها از آزمونهاى تحليل كوواريانس تكمتغيره (Ancova)، تحليل واريانس جندمتغيره

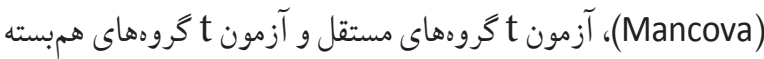

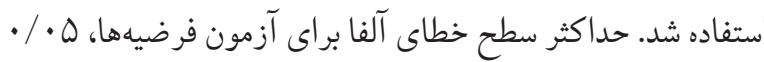

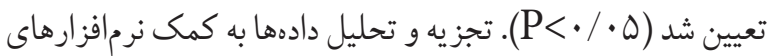

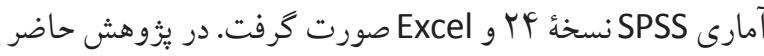

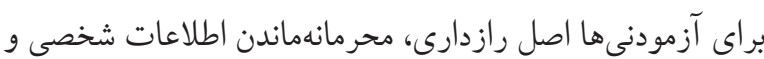
تحليل دادهها بهصورت كلى بيان شد. شركت كنند كان نيز رضايتنامة كتبى شركت آكاهانه در يُوهش را تكميل كردند. يافتنه ما در جدول ا، ويثگى هاى دموكرافيك تأهل، جنسيت، تحصيلات و دامنه سنى افراد مبتلا به MS به تفكيك گروههاى درمان شناختى-رفتارى و مبتنى بر اميد گزارش شد. فراوانى هر گروه 10 نفر و فراوانى

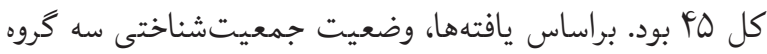
كنترل، شناختى-رفتارى و اميددرمانى مشابه يكديكر است. درصد فراوانى افرادى كه تحصيلات دييلم و پِايينتر دارند در گروه كنترل

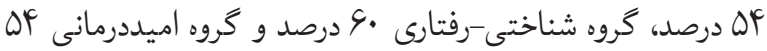

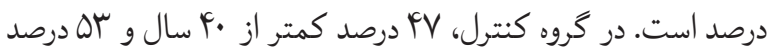

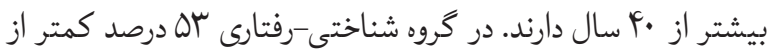

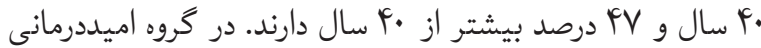

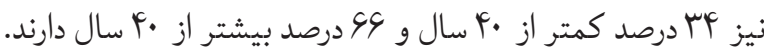

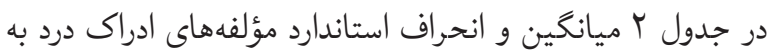

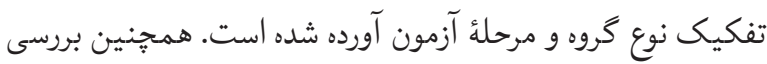
ييش فرض ها نشان مى دهد فرض نرمالبودن و همخنى واريانسها

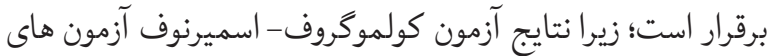

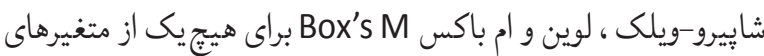




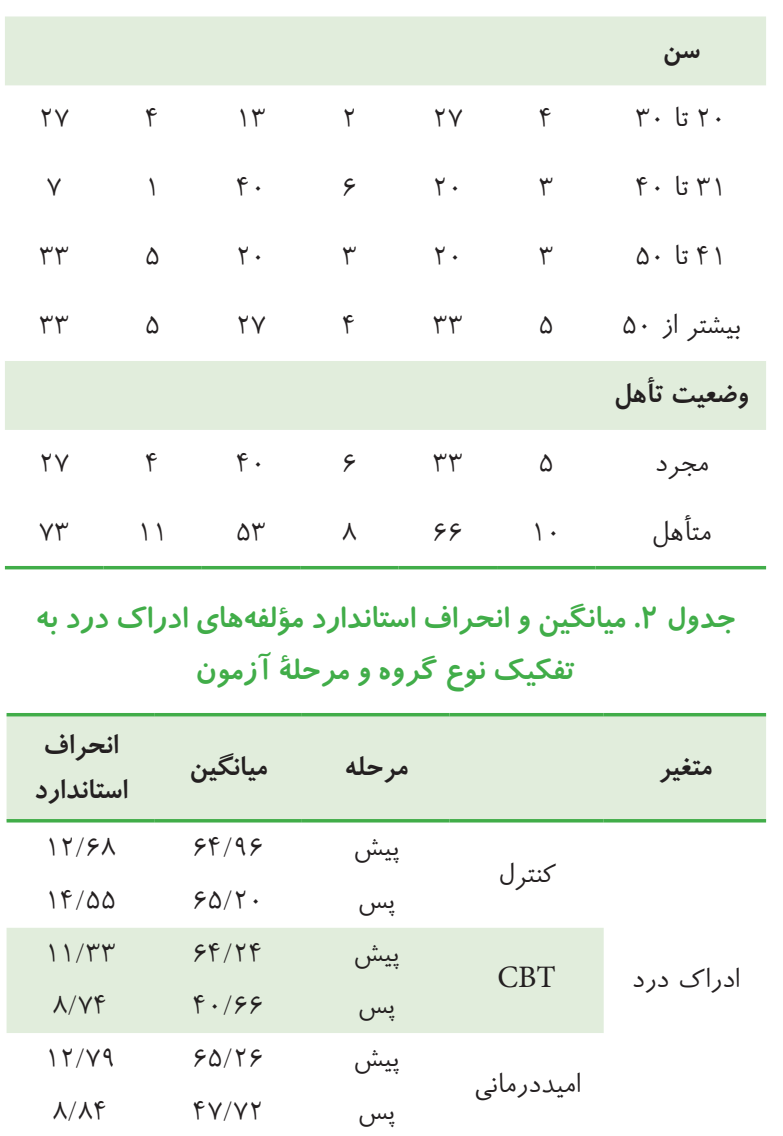

جدول س. آزمون شاييرو-ويلك

\begin{tabular}{|c|c|c|c|c|}
\hline كشيدگى & كجى & معنى دارى & آماره & متغير \\
\hline $1 / \mu$. & $\cdot / \mathrm{IVT}$ & $\cdot|r s|$ & - $/ 9 \mu \mathrm{r}$ & درد حسى \\
\hline.$- / 199$ &.$/ 994$ & $\cdot / \cdot r$. & · / ASY & درد عاطفى \\
\hline$-1 / 4 \wedge$ & . & .1 .19 & $\cdot / 1 \Delta \Delta \Delta$ & ارزيابى درد \\
\hline$-\cdot /$ rq &.$|F F|$ &.$|r s|$ &.$/ 9 \mu \mathrm{F}$ & دردهاى گوناگون \\
\hline $1 / r \Delta$ & q & $\begin{array}{l}\text { - /IOF } \\
\cdot / F \wedge\end{array}$ &.$/ 919$ & ادراك درد (كل) \\
\hline
\end{tabular}

جدول ع. نتايج آزمون همكنى ماتريسهاى واريانس-كوواريانس (آزمون امباكس) ماترسي)

\begin{tabular}{|c|c|}
\hline نوع آماره & 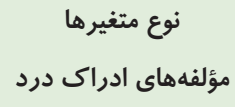 \\
\hline Box’s M & $r \Delta / \Delta 1$ \\
\hline F آمارة F & $1 / 9 \mu$ \\
\hline درجة آزادى & 1. \\
\hline سطح معنى دارى & /.9 \\
\hline
\end{tabular}

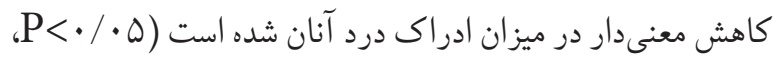

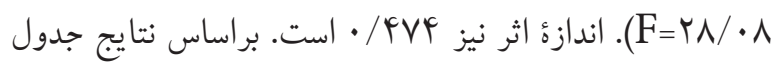

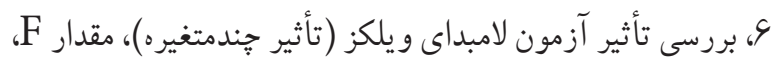

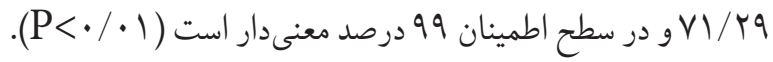
اين مقوله نشان مىدهد اثر مداخله در حداقل يكى از متغيرهاى

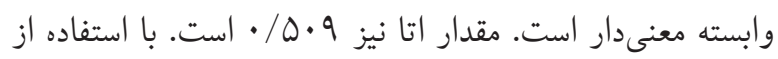

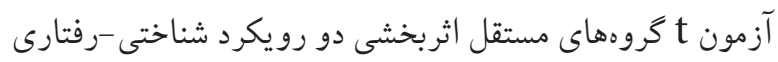

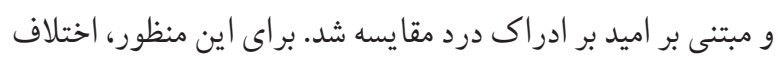

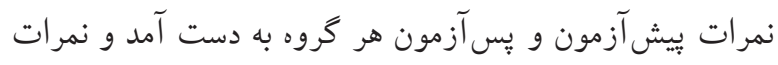

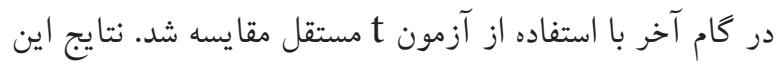

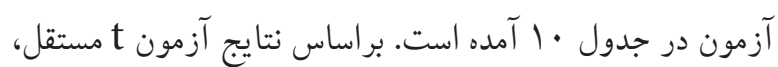

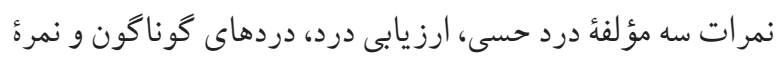

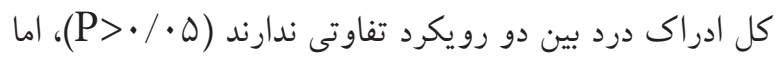

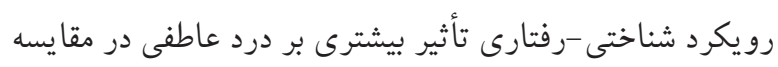

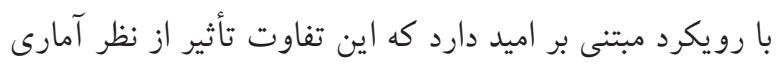

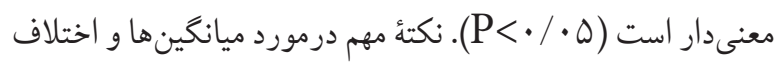

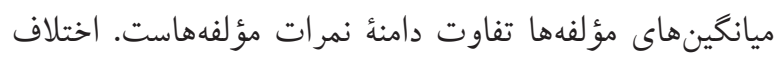

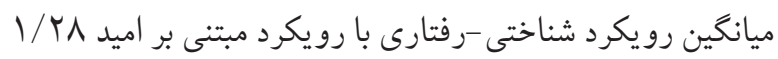

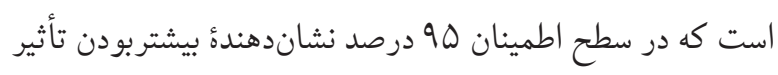
رو يكرد شناختى -رفتارى است.

جدول ا. ويثَى هاى دموَّرافيك افراد مبتلا به MS به به تفكيك كروههاى درمان شناختى -رفتنارى و مبتنى بر اميد

\begin{tabular}{|c|c|c|c|c|c|c|}
\hline \multicolumn{2}{|c|}{ كروه مبتنى بر اميد } & \multicolumn{2}{|c|}{ كروه شناختى - رفتاى } & \multicolumn{2}{|c|}{ كروه كنترل } & \multirow{2}{*}{ ويزَى } \\
\hline فراوصى & فراوانى & فراوانى & فراوانى & فراوانى & فراوانى & \\
\hline & & & & & & ميزان تحصيلات \\
\hline rV & r & rV & r & rV & r & تا دييلم \\
\hline rV & r & r & $\Delta$ & rV & r & دييلم \\
\hline r. & 9 & $r$. & $r$ & $\mu$ & $\Delta$ & فوقدييلم 9 \\
\hline v & 1 & r. & r & ir & r & فوقليسانس 9 \\
\hline
\end{tabular}


جدول 9. نتايج آزمون Mancova بهمنظور بررسى تفاوت

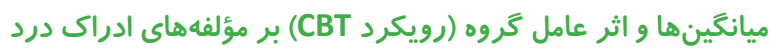

\begin{tabular}{|c|c|c|c|c|c|c|}
\hline اندازة & معنىدارى & Fقدار F F & درجأ & مجذانگين & متغير وابسته & منبع اثر \\
\hline$\cdot / F \mid \wedge$ & $<\cdot / \cdots 1$ & س 19/r & 1 & $G \cdot / \uparrow \Delta$ & درد حسى & \\
\hline . $/ r \Delta \Delta$ & $<\cdot / \cdots 1$ & $I r / V$. & 1 & $\Delta \Lambda / \Delta V$ & درد عاطفى & كروه \\
\hline$\cdot / \mathcal{F} \wedge$ & $<\cdot 1 \cdots 1$ & ऍ^/r. & 1 & $\vee q / f$. & ارزيابى درد & (اميددرمانى \\
\hline.$/ 011$ & $<\cdot / \cdots 1$ & FF/Vq & 1 & $90 / 11$ & دردایاگون & \\
\hline
\end{tabular}

جدول • ا. مقايسه ميزان اثربخشى دو رويكرد شناختى -رفتارى و مبتنى بر اميد بر ادراى درد

\begin{tabular}{|c|c|c|c|c|c|}
\hline \multirow{2}{*}{ معنىدارى } & \multirow{2}{*}{ مقدار } & \multirow{2}{*}{ تفانغين } & \multicolumn{2}{|c|}{ اختلاف ميانغين دو } & \multirow[t]{2}{*}{ متغيرها } \\
\hline & & & اميددرمانى & CBT & \\
\hline$>\cdot / \cdot 0$ & $1 / 01$ & $r / \Delta r$ & $9 / \cdot 1$ & $11 / \Delta F$ & درد حسى \\
\hline$<\cdot / \cdot \Delta$ & $r / 4$. & $1 / r A$ & $r / \Delta \varphi$ & $r / A r$ & درد عاطفى \\
\hline$>\cdot / \cdot \Delta$ & $1 / 100$ & $\mathrm{rV} /$. & .199 & 吾 & ارزيابى درد \\
\hline$>\cdot / \cdot 0$ & $1 / 49$ & I/^s & $F / .1$ & $\wedge \vee / \Delta$ & دردهاى گوناگون \\
\hline$>\cdot / \cdot 0$ & $1 / 9 \pi$ & $s / \cdot r^{r}$ & $I V / \Delta F$ & $r \mu / \Delta \Lambda$ & (نمرة كل) درد) \\
\hline
\end{tabular}

براساس نتايج آزمون t مستقل، در نمرات سه مؤلفة درد حسى، ارزيابى درد، دردهاى گوناكون و نمرءٔ كل ادراك درد ميان دو رويكرد تفاوتى وجود ندارد (ه •/P> (P)، اما رويكرد شناختى -رفتارى در مقايسه با رويكرد مبتنى بر اميد، تأثير بيشترى دور دود بر درد عاطفى دارد و اين تفاوت تأثير از نظر آمارى معنىدار است

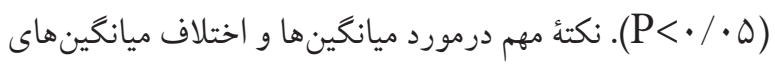
مؤلفهها اين است كه دامنهُ نمرات مؤلفهها متفاوت است. اختلاف

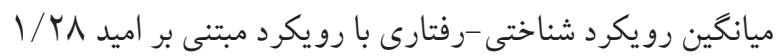
است كه در سطح اطمينان هو درصد نشاندهندهُ بيشتربودن تأثير رويكرد شناختى -رفتارى است.
جدول ه. آزمون همخنى واريانسهاى متغيرهاى وابسته در ميان

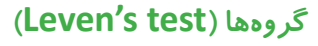

\begin{tabular}{|c|c|c|}
\hline سطح معنىدارى & Fقدار F F & متغير ها \\
\hline$\cdot / 9 \Delta V$ & $\cdot / r \cdot \Lambda$ & درد حسى \\
\hline$\cdot / \vee \wedge I$ & $\cdot / \cdot \wedge$ & درد عاطفى \\
\hline$\cdot /$ ศ 9 & -/Var & ارزيابى درد \\
\hline$\cdot / \cdot \wedge r$ & $r / \Delta 1$ & دردهاى گوناگون \\
\hline$\cdot / \vee q$. & $\cdot / \cdot V^{F}$ & ادراك درد (كل) \\
\hline
\end{tabular}

جدول \&. نتايج آزمون تحليل كوواريانس تكمتغيرة Ancova با هدف بررسى تأثير رويكرد شناختى -رفتارى بر ادراك درد دود در افراد مبتلا به مئنى

\begin{tabular}{|c|c|c|c|c|c|c|}
\hline اندازة & معنىدارى سطح & آمارة F F & آزادى درجه & مجذورات & منابع تغيير . & متغير وابسته \\
\hline \multirow[t]{2}{*}{.$/ \Delta r}$. & $<\cdot / \cdot 1$ & $r N / s F$ & 1 & $G \wedge / T r$ & 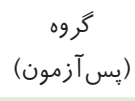 & \multirow[t]{2}{*}{ ادراى درد } \\
\hline & & $r / \uparrow$. & 1 & N/VD & مقدار خطا & \\
\hline
\end{tabular}

جدول V. نتايج آزمون Mancova بهمنظور بررسى تفاوت ميانگينها و اثر عامل گروه (رويكرد درد در بيماران مبتلا به بهود

\begin{tabular}{|c|c|c|c|c|c|c|}
\hline اندازء & معنىدارى & مقدار F & درجة & مجذانغين & متغير وابسته & منبع اثر \\
\hline$\cdot / \uparrow \wedge \wedge$ & $<\cdot / \cdot \cdot$ & $r F / G \Lambda$ & 1 & $9 \cdot / 91$ & درد حسى & \multirow{4}{*}{$\begin{array}{l}\text { گ } \\
\text { (CBT) }\end{array}$} \\
\hline$\cdot / r 10$ &.$/ \cdot r$ & $S / \wedge D$ & 1 & rV/rA & درد عاطفى & \\
\hline ./GST & $<\cdot / \cdots 1$ & $r \Delta / 1 r$ & 1 & $|r V / \Lambda|$ & ارزيابى درد & \\
\hline - $/ \Delta r \Delta$ & $<\cdot / \cdot \cdot 1$ & $r q / r r$ & 1 & $1 \cdot V / \Delta r$ & دورناگون & \\
\hline
\end{tabular}

جدول ^. نتايج آزمون تحليل كوواريانس تكمتغيره Ancova با

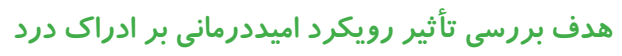

\begin{tabular}{|c|c|c|c|c|c|c|}
\hline اندازة & معنىدارى سطح & آمارة F F & درجاد & مجذورات مجموع & منابع تغيير & متغير وابسته \\
\hline \multirow[t]{2}{*}{$\cdot / F V F$} & $<\cdot / \cdot 1$ & $r \Lambda / \cdot \Lambda$ & 1 & $\Delta r / 1 s$ & 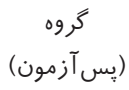 & \multirow[t]{2}{*}{ ادراك درد } \\
\hline & & $F / 19$ & 1 & q/Ar & مقدار خطا & \\
\hline
\end{tabular}


با تصحيح تفسيرهاى نابجا، هدايت خودكويىهاى منفى، اصلاح

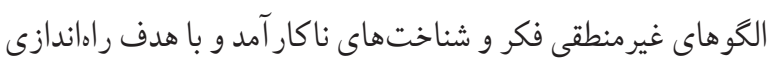

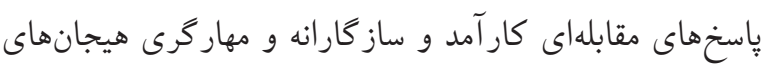

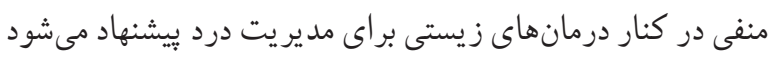

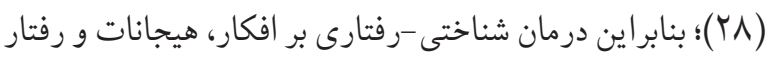

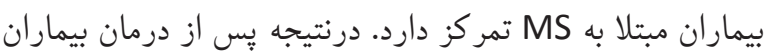

$$
\text { درد كمترى گز ارش شده است. }
$$

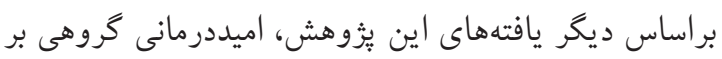

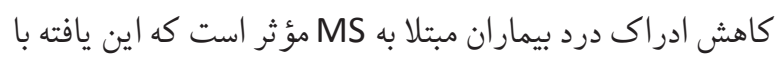
نتايج يُزوهش عابدينى( • م) و همكاران همسوست. در تبيين اين يافته مى توان كفت بيمارى كه تحت مداخلة اميددرمانى قرار مى كيرد،

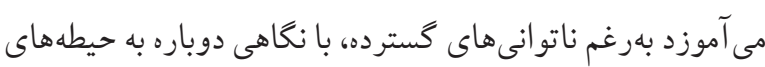

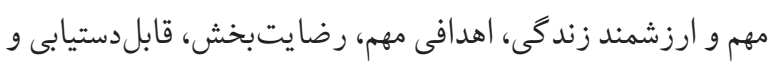

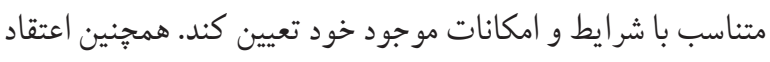

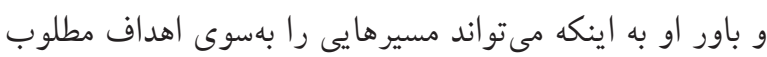

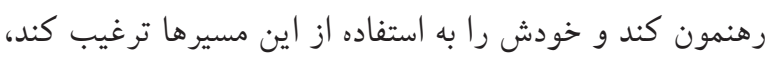

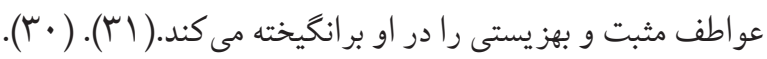

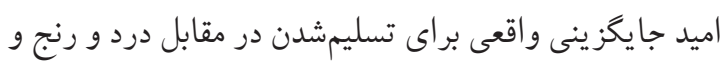

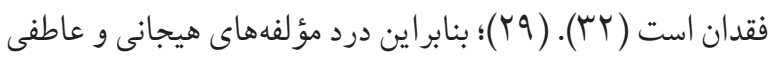
دارد. اميددرمانى نيز با افزايش عواطف و هيجانات مثبت مى تواند در كاهش درد مؤثر باشد. افراد اميدوار اهداف بيشترى براى خود دارند و موفقيت بيشترى در دستيابى به اهدافشان تجربه مى كنند؛ ״س شاد كامى بيشتر، فشار روانى كمتر و مكانيسمهاى مقابلهاى دئي

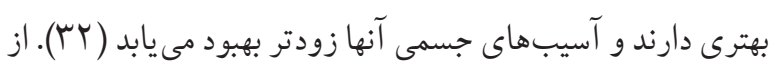

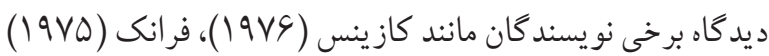

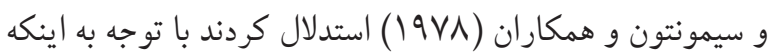
نقش درگيرى با افكار و هيجانات منفى در نقصان سلامتى بيان

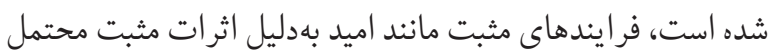

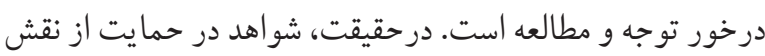

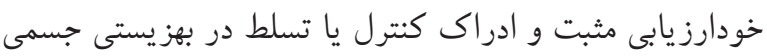
و روانى همسو شدند (YT). درمجموع مى توان كفت به كاركيرى
يُزوهش حاضر با هدف بررسى مقايسةُ تأثير دو رويكرد گروه درمانى لخى

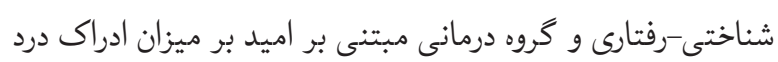
بيماران مبتلا به MS صورت كرفت. براساس يافتهها، هر دو رويكرد

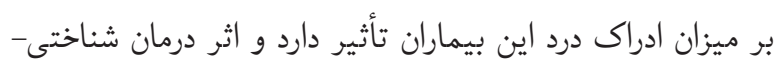

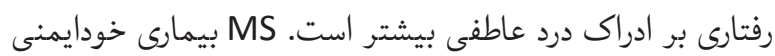
است. بايد توجه داشت كه وضعيت روانى فرد بر عملكرد سيستم

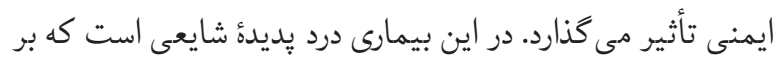
كيفيت زندكى و سلامت روان بيماران تأثيرى منفى دارد؛ بنابراين مداخلات روانشناختى در اين زمينه مهم و ضرورى است. درنتيجه هدف اين يثوهش مقايسة اثربخشى درمان شناختى-رفتارى و درمان مبتنى بر اميد بر كاهش ادراك درد در افراد مبتلا به MS است.

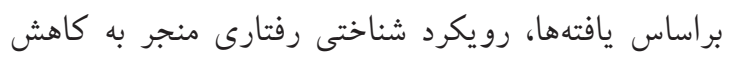

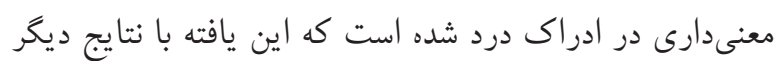

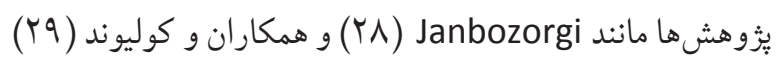
و همكاران مطابقت دارد. مى توان كفت درمان شناختى -رفتارى

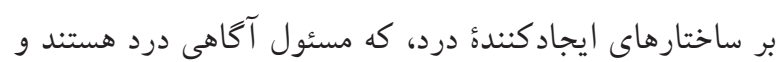

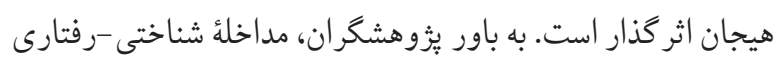

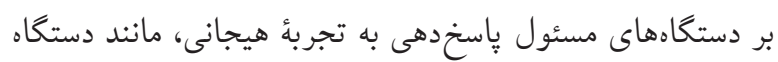

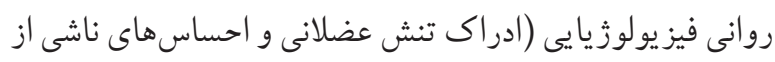

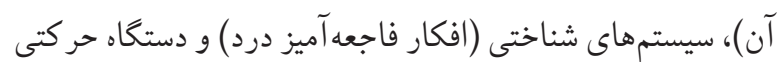

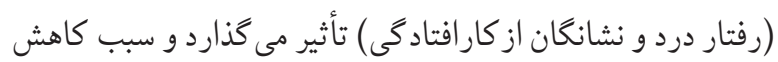

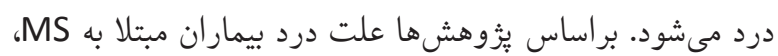
باورهاى شناختى مخرب، يعنى باورهاى غيرمنطقى منفى مانند

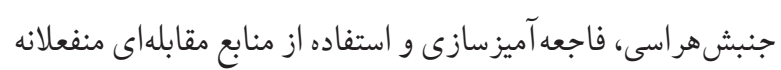

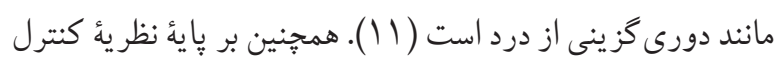

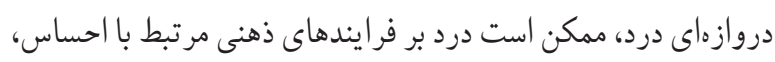

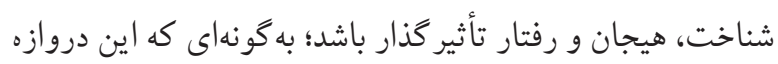

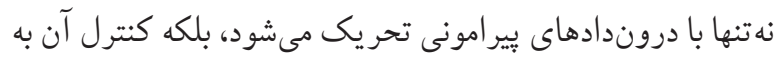

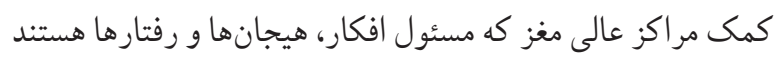

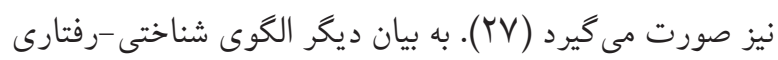


بهترين پاسخ، پاسخى است كه كو ياى وضعيت واقعى آنها باشد و اينكه دادها محرمانه مىمانند و بهصورت كلى تحليل اليال مىشوند،

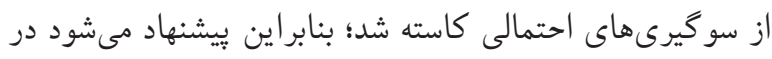

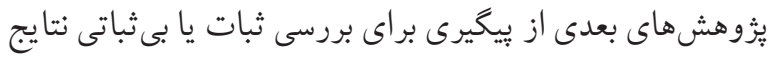

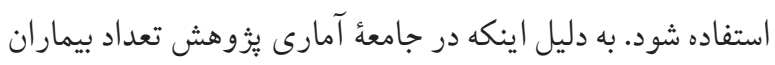

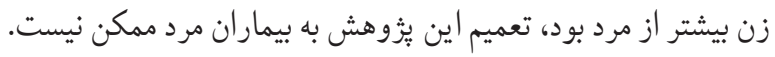

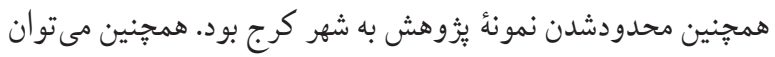
اين يثوهش راد در ساير كروهها انجام داد تا بتوان در تعميم نتايج

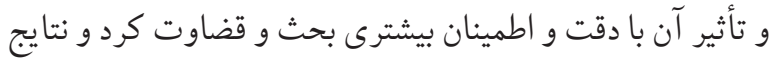

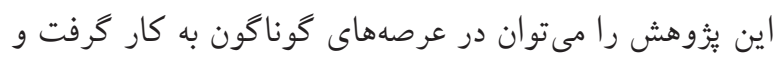

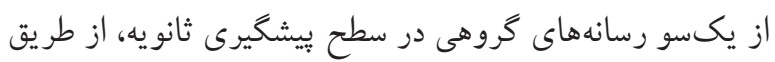

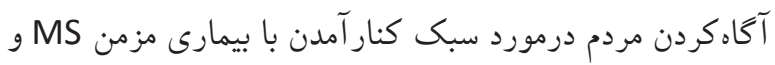

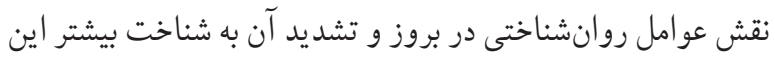

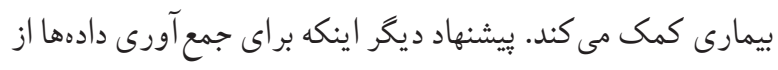

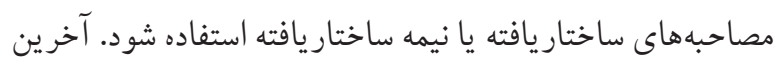
بيشنهاد اينكه مى توان به مقايسة اثربخشى درمان شناختى - رفتارى

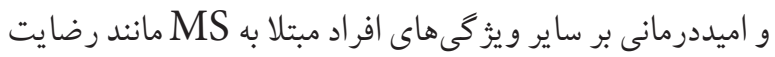

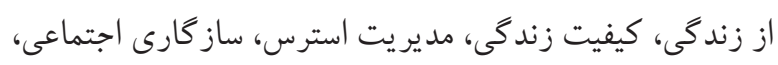

$$
\text { نتيجه گيرى زناشويى برداخت. }
$$

براساس نتايج يُوهش هر دو روش درمان شناختى-رفتارى و درمان مبتنى بر اميد بهطور معنى دارى سبب كاهش ادراك درد افراد مبتلال

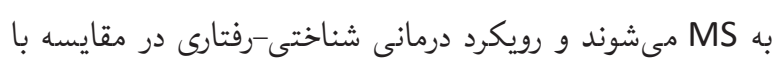

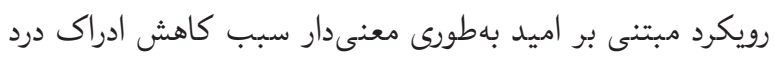

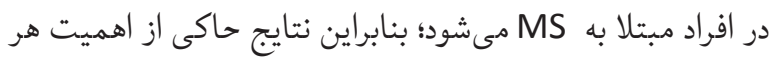

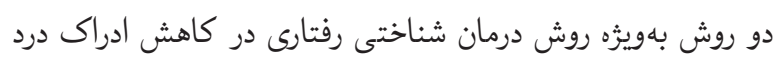

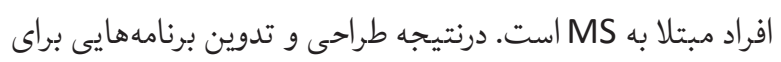

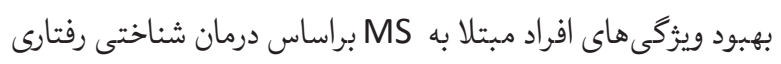

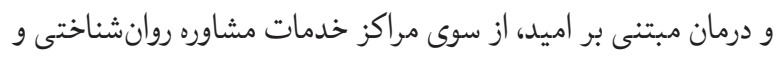

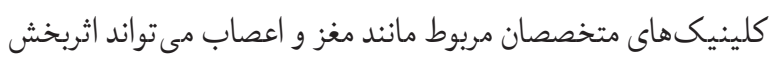
واقع شود. همجنين با توجه به مؤثرتربودن درمان شناختى-رفتارى در
راهبردهاى شناختى -رفتارى در مدير يت درد و اميددرمانى، افزون

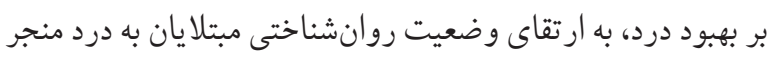
مىشود و كامى مؤثر براى صرفهويى در مصرف دارو و كاهش عوارض مصرف داروهاست. براساس ياقتهاى ديكر اين يُوهش، ميزان اثربخشى دو درمان

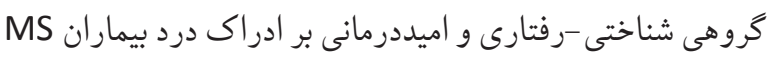
متفاوت است و اثربخشى درمان شناختى رفتارى، بهويثه در مؤلفه درد

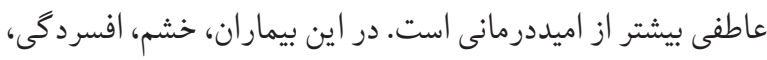

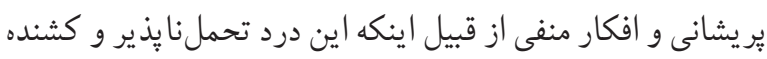

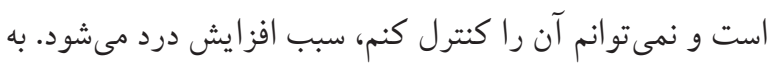

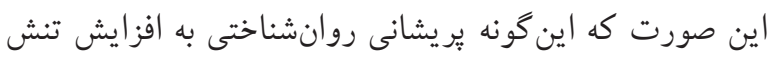

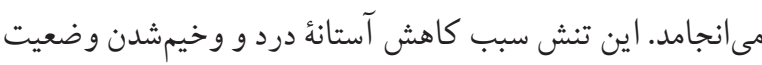

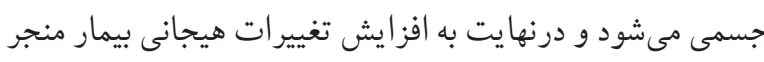

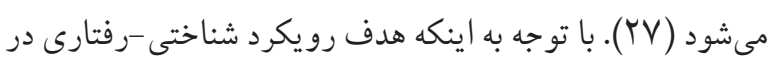

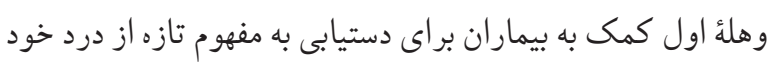

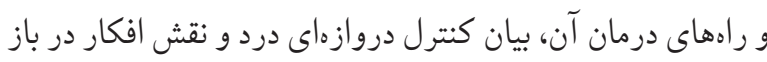

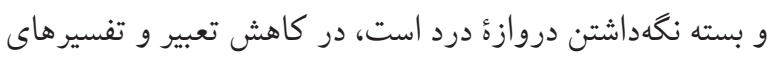
غلطا، فاجعهآفرينى و غير قابل كنترل دانستن درد اثر كذار است.

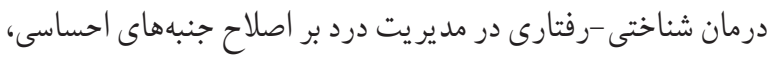
عاطفى، شناختى و رفتارى تجربة درد تمر كز مى كند و به بيماران

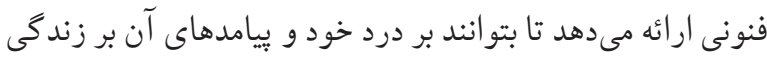

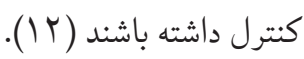
مهمترين محدوديتهاى اين يُوهش استفاده از روش نمونه كيرى

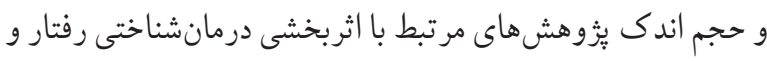

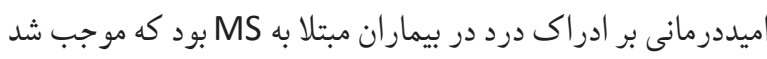

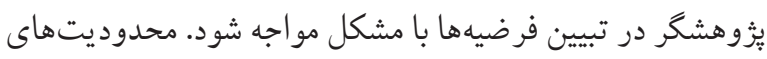

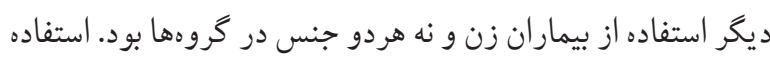

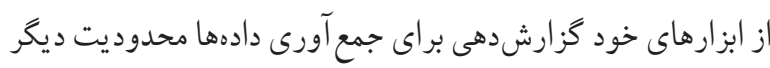

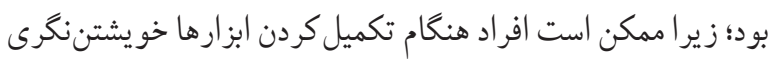

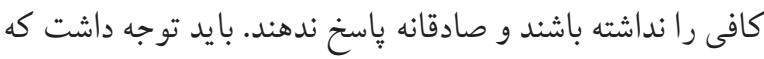
در اين يُزوهش با بيان اينكه پاسخ صحيح و غلطى وجود ندارد و 
عوامل زيستى، روانى و اجتماعى مانند ترس از صدمه و آسيب، ادراك

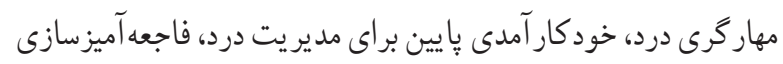
و ياسخهاى رفتارى مرتبط مانند اجتناب از فعاليت، اشتغال به فعاليت خيلى زياد يا برعكس كمتحركى بهطور متناوب و كوش به زنكى

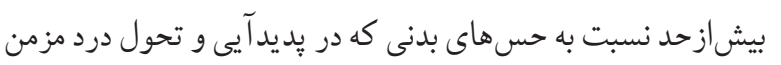
و ناتوانىهاى متعاقب آن نقش دارند، مؤثر واقع مىشوند. به بيان ديخر الخوى شناختى - رفتارى با تصحيح تفسيرهاى نابجا، هدايت خود گو يىهاى منفى، اصلاح الكوهاى غيرمنطقى فكر و شناختهاى ناكار آمد و با هدف راهاندازى ياسخهاى مقابلهاى كار آمد و ساز گارانه و مهار گرى هيجانهاي منفى در كنار درمانهاى زيستى براى مديريت

$$
\text { درد يِيشنهاد مى شوند. }
$$

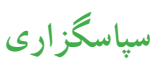

از همةٌ بيماران و يزشكانى كه يزوهشگر را در اين يثوهش يارى

$$
\text { كردهاند، نهايت قدردانى و سياس را دارم. }
$$

\section{Refernces}

1- Fischer A, Heesen C, Gold SM. Biological outcome measurements for behavioral interventions in multiple sclerosis. Therapeutic advances in neurological disorders. 2011 Jul;4(4):217-29. https://doi.org/10.1177/1756285611405252 PMid:21765872 PMCid:PMC3131172

2- Noseworthy JH, Lucchinetti C, Rodriguez M. weinshenker BG. Multiple sclerosis. New Eng. J. Med. 2000;343:938-52. https://doi.org/10.1056/NEJM200009283431307 PMid:11006371

3. Jafari $Y$, Vahedian-Shahroodi M, Tehrani H, Haresabadi M, Shariati M. The relationship between caregivers' health literacy and the behavior of women with multiple sclerosis. Iranian Journal of Obstetrics, Gynecology and Infertility. 2018;21(7):71-64, https://doi.org/10.22038/ ijogi.2018.11798

4. Omrani S, Mirzaeian B, Aghabagheri H, Hasanzadeh R, Abedini M. The Effectiveness of Cognitive-Behavioral Therapy in a Group Method on Life expectancy in Patients with Multiple Sclerosis. J Mazandaran Univ Med Sci.2012;22(93):58-65.

5. Sadock B,Sadock V. Synopsis of Psychiatry Behavioral Sciences / Clinical Psychiatry, translated by Nosratollah Pourfakheri, Tehran, Shahr Ab;2012.

6. Mirhashemi M, Najafi F. Effectiveness of the solution-

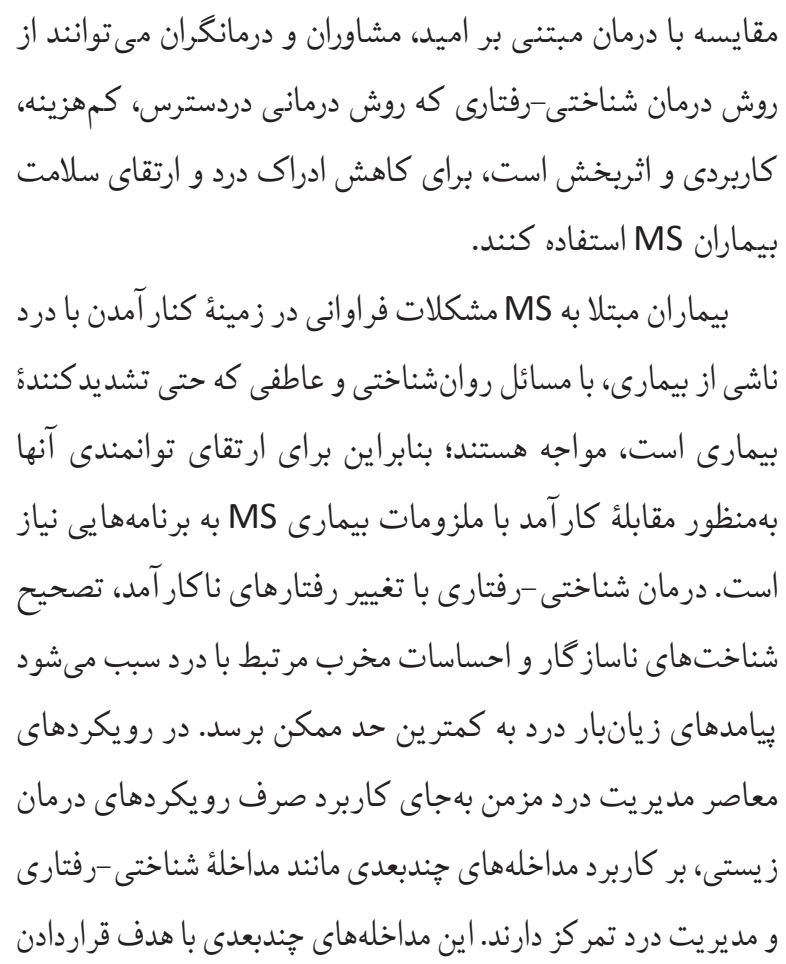

based treatment therapy on resiliency and the sense of coherence of multiple sclerosis patients.J Tehran Azad Univ Med Sci.2014;24(3):175-181.

7. Rapaport B, Kraceski S. Multiple sclerosis and stress. Neurology 2012;79:47-9. https://doi.org/10.1212/WNL.0b013e318265751f PMid:22851726

8. Moss-Morris R, McCrone P, Yardley L, van Kessel K, Wills G, Dennison L.Apilotrandomised controlledtrialofan Internetbased cognitive behavioural therapy self-management programme (MS Invigor8) for multiple sclerosis fatigue. Behaviour research and therapy. 2012 Jun 1;50(6):415-21. https://doi.org/10.1016/j.brat.2012.03.001 PMid:22516321

9. Farhang S. Comparison of the Effectiveness of Cognitive Therapy and Supportive Therapy on Psychological Adjustment in Patients with MS, MSc in Clinical Psychology, Faculty of Literature and Humanities, Mohaghegh Ardabili University;2011. [Persian].

10. MCcabe MP. Mood and self-esteem of persons with multiple sclerosis following an exacerbation. Journal of psychosomatic research. 2005 Sep 1;59(3):161-6. https://doi.org/10.1016/j.jpsychores.2005.04.010 PMid:16198189

11. Turk DC, Gatchel RJ, editors. Psychological approaches to 
pain management: A practitioner's handbook. Guilford publications; 2018 May 7.

12. Kar A. Positive Psychology: The Science of Happiness and Human Strengths, Translated by Pasha Sharifi, Tehran: Sokhan;2008.

13. Snyder CR, editor. Handbook of hope: Theory, measures, and applications. Academic press; 2000 Jun 7.

14. Jopson NM, Moss-Morris R. The role of illness severity and illness representations in adjusting to multiple sclerosis. Journalofpsychosomaticresearch.2003Jun1;54(6):503-11. https://doi.org/10.1016/S0022-3999(02)00455-5

15. Donna JB, Cathy B. An overview of assistive technology for persons with multiple sclerosis. J Rehab Res develop 2002; 39(2): 299-312.10. Turk DC, Gatchel RJ. Psychological approaches to pain management: a practitioner's handbook: Guilford Publications; 2013.

16. Cheavens JS, Feldman DB, Gum A, Michael ST, Snyder CR. Hope therapy in a community sample: A pilot investigation. Social indicators research. 2006 May 1;77(1):61-78. https://doi.org/10.1007/s11205-005-5553-0

17. Robertson D. The Philosophy of Cognitive Behavioral Therapy: Stoicism as Rational and Cognitive Psychotherapy. London: karnac; 2010.P.176-90.

18. Kazemi Nezhad S, Comparison of the effectiveness of two methods of cognitive-behavioral group counseling and therapeutic mean on reduction of anxiety in patients with MS in Yazd province, Graduate dissertation, Allameh Tabatabaei University; 2010.

19. Atkinson RL, Atkinson RC, Smith EE, Bern DJ, NolenHoeksema S. Hilgard,s introduction to psychology. 13th ed. Fort Worth, TX: Harcourt Brace; 2000.

20. Wenzel A. Basic strategies of cognitive behavioral therapy. Psychiatric Clinics. 2017 Dec 1;40(4):597-609. https://doi.org/10.1016/j.psc.2017.07.001 PMid:29080588

21. Hashemi N, Ghayour Baghbani SM, Khadivi G, Hashemian Nejad F, Ashoori J. The effectiveness of cognitive behavioral therapy and schema therapy on happiness and mental health of nursing students. Journal of Clinical Nursing and Midwifery. 2016;5(2).

22. Sharifian Y, Khalili M, Hasan Zadeh Pashang S,Kamarzarin $H$,Thaghi Zadeh M.The Effectiveness of CognitiveBehavioral Group Therapy on Mental Health of MS Patients,
Initial and Progressive Type, J Urmia Med.2013;24(9):623636.

23. Vesal M, Mollazadeh J,Taghavi M,Nazarinia M. A Survey on the Prophecy of Depression by Prediction of Pain and Quality of Sleep with Intervention of Pain Catastrophizing in Patients with Elderly Rheumatism, J Anesth Pain.2015;5(4):69-80.

24. Hamzeh pour Haghighi T, Dousti Y, Mirzaeian B, Fakhri M. The Effectiveness of Group-Based Cognitive-Behavioral Therapy on Perceived Pain and Perception of Pain in Patients with Rheumatoid Arthritis, Sci J Kurdistan Univ Med Sci.2015;20(3):45-57.

25. Farshad B. The Basics of Hope \& Hope Therapy. Tehran: Danzheh:2011.

26. Craig W. Cognitive Behavioral Therapy for Chronic Medical Diseases: Practical guide for evaluation and treatment, Translated by Reza Moloudi \& Katayun Fatahi, Tehran: Arjmand;2011.

27. Sanderson C.Health Psyclology, Translation by Jomehri F, Meschi and et al. Karaj:Sarafraz:2013.

28. Janbozorgi M, Golchin N,Alipour A, Agah Haris M. The Effectiveness of Group Cognitive Behavioral Therapy in Reducing the Severity of Pain and Psychological Distress in Women with Chronic Low Back Pain. Iran J Psychiatry Clin Psychol.2013;19(2):102-108

29.Kulivand P, Nazari Mahin A, Jafari R . The effect of cognitive behavioral therapy on reducing distress in patients with chronic pain. J Khatam Healing.(2015):3(3):64-69. https://doi.org/10.18869/acadpub.shefa.3.3.63

30.Abedini E: Ghanbari-Hashem-Abad B.A : Talebian-Sharif J, Effectiveness of Group Therapy Based on Hope Approach on Hope and Depression in Women with Multiple Sclerosis, J Clin Psychol.2016:2(30):1-11 .

31. Sivly A, Biller H. The Power Of Hope, Translated by Maryam Taghdisi. Tehran: Qoqnoos:2017.

32. Müller R, Gertz KJ, Molton IR, Terrill AL, Bombardier $\mathrm{CH}$, Ehde DM, Jensen MP. Effects of a tailored positive psychology intervention on well-being and pain in individuals with chronic pain and a physical disability. The Clinical journal of pain. 2016 Jan 1;32(1):32-44. https://doi.org/10.1097/AJP.0000000000000225

PMid:25724020 